\title{
How Does Inhibition of the Renin-Angiotensin System Affect the Prognosis of Advanced Gastric Cancer Patients Receiving Platinum-Based Chemotherapy?
}

\author{
Seung Tae Kim Kyong Hwa Park Sang Cheul Oh Jae Hong Seo Jun Suk Kim \\ Sang Won Shin Yeul Hong Kim \\ Division of Hematology-Oncology, Korea University College of Medicine, Seoul, South Korea
}

\section{Key Words}

Renin-angiotensin system · ACEI/ARB · Chemotherapy

\begin{abstract}
Background: The renin-angiotensin system (RAS) is related to the regulation of cell proliferation, angiogenesis, and tumor progression. Patients and Methods: We retrospectively analyzed the effect of angiotensin l-converting enzyme inhibitors (ACEls) and angiotensin II type-1 receptor blockers (ARBs) in 63 patients with advanced gastric cancer (AGC) with platinum-based chemotherapy. All patients analyzed had received medications for hypertension at the diagnosis of AGC. Patients were divided into two groups: an ACEl/ARB group $(n=30)$ and a non-ACEI/ARB group $(n=33)$. Results: Patient characteristics were not different between patients with and without ACEI/ARB. The response rate for all patients was $25.4 \%$ and the disease control rate was $77.8 \%$. The median progression-free survival (PFS) for first-line chemotherapy was 5.5 months $(95 \% \mathrm{Cl} 3.71-7.29)$ in the ACEI/ARB group and 4.3 months $(95 \% \mathrm{Cl} 2.39-6.21)$ in the non-ACEI/ARB group $(p=0.506)$. There was a significant difference in overall survival (OS) in the ACEI/ARB group compared to the nonACEI/ARB group (median OS: 8.2 vs. 13.9, $p=0.0095$ ). In mul-
\end{abstract}

tivariate analysis, the use of ACEI/ARB was a significant independent prognostic factor for OS $(p=0.039)$ but not for PFS. Conclusion: ACEI/ARB in combination with standard chemotherapy might improve survival in patients with AGC and hypertension. These results support further investigation into the anticancer effects of ACEL/ARB.

Copyright $\odot 2012$ S. Karger AG, Basel

\section{Introduction}

Gastric cancer (GC) is a leading cause of cancer death worldwide; it ranks second in global cancer mortality following lung cancer [1]. More than half of all patients diagnosed with GC will have unresectable disease [2]. Even patients with an operable tumor have high rates of both local and distant recurrence [3-6]. Systemic chemotherapy is the standard approach for the treatment of unresectable and/or recurrent GC. Many combination regimens have shown a response rate (RR) of $35-45 \%$ and are able to achieve better RR. Various combination chemotherapy regimens have been shown to be effective in advanced GC (AGC). There is currently no single well-established standard of care, but fluoropyrimidine-based

\section{KARGER}

Fax +4161306 1234 E-Mail karger@karger.ch www.karger.com
(C) 2012 S. Karger AG, Basel

0030-2414/12/0836-0354\$38.00/0

Accessible online at:

www.karger.com/ocl
Yeul Hong Kim, MD

Division of Hematology-Oncology, Department of Medicine

Korea University Anam Hospital, Korea University College of Medicine, 126-1

Anam-dong 5-ga, Seongbuk-gu, Seoul 136-705 (South Korea)

Tel. +82 2920 5569, E-Mail yhk0215@korea.ac.kr 
and/or platinum-based combinations with or without a third drug (usually docetaxel or epirubicin) are the most widely used worldwide [7-9]. Despite the recently reported benefits of combination therapies, the prognosis of AGC remains poor, and new treatments including molecular targeted agents are challenged.

The renin-angiotensin system (RAS) is involved with the regulation of arterial pressure. RAS inhibition represents a key target in the treatment of hypertension. Angiotensin I-converting enzyme inhibitors (ACEIs) and angiotensin II type-1 receptor blockers (ARBs) are some of the most widely used antihypertensive drugs. Large epidemiological studies revealed potential protective effects against cancer risk $[10,11]$ even though the results remain controversial. Thus, the potential role of the local RAS in carcinogenesis has attracted substantial attention. The local RAS reportedly promotes angiogenesis and proliferation via vascular endothelial growth factor (VEGF) expression or epidermal growth factor receptor (EGFR) expression $[12,13]$. ARB and ACEI are known to act on tumor progression via two different mechanisms: inhibition of cancer proliferation and/or inhibition of neovascularization. Recently, overexpression of angiotensin II type-1 receptor has been observed in vivo in different tumors, including: estrogen receptor-positive breast cancers [14], glioblastomas [15], ovarian cancers [16], squamous cell carcinomas of the skin [17], and GC [18]. Noguchi et al. [19] demonstrated that combined gemcitabine and ARB showed synergistic inhibition of tumor growth in murine pancreatic cancer. Nakai et al. [20] also reported that ACEI/ARB in combination with gemcitabine might improve clinical outcomes in patients with advanced pancreatic cancer. In a human gastric xenograft, ACEI with or without cisplatin was also reported to inhibit tumor growth [21]. Thus, adding ACEI/ARB to chemotherapy may improve survival outcomes in patients with AGC.

We therefore conducted a retrospective study to identify the role of RAS inhibition in outcomes of patients with AGC.

\section{Patients and Methods}

\section{Patients}

We retrospectively reviewed the records of 63 patients with metastatic or recurrent GC who had been treated with systemic chemotherapy at Korea University Anam Hospital, Seoul, Korea, between May 2002 and May 2010. All patients had pathologically or cytologically proven metastatic or recurrent GC and received medications for hypertension at the diagnosis of metastatic or re- current GC. The following clinical data were collected from the medical records of each patient: physical examination, surgical and pathologic reports, and imaging. Medical information including chemotherapy regimens, response, date of progression, last follow-up, and death were collected. In addition, the use of hypertension medications including ACEIs or ARBs was retrieved from the medical records, and patients were divided into two groups: an ACEI/ARB group $(\mathrm{n}=30)$ and a non-ACEI/ARB group $(\mathrm{n}=33)$.

\section{Chemotherapy}

The decision to conduct chemotherapy or not depended, in all cases, on the discussion between the physician and the patient. The chemotherapy regimen to be used was determined by the physician. Fluoropyrimidine-based and/or platinum-based combinations with or without a third drug (usually docetaxel or epirubicin) were usually proposed to patients. Chemotherapy was repeated every 2-4 weeks according to the regimen. All tumor measurements were assessed after every 2 or 3 cycles of chemotherapy via computed tomography (CT) scans and other tests that had been used initially to stage the tumor. Responses were classified according to Response Evaluation Criteria in Solid Tumors (RECIST) 1.0.

\section{Statistical Analysis}

Treatment outcomes were: RR, disease control rate, overall survival (OS), and progression-free survival (PFS). Tumor response was determined according to RECIST 1.0. The efficacy analysis was based on the intent-to-treat population. OS was defined as the time between the date of the diagnosis of recurrence or metastatic disease and the date of death from any cause. PFS was defined as the time from the date of the diagnosis of recurrence or metastatic disease to the date of disease progression or death from any cause. The Kaplan-Meier method was employed to estimate the probability of survival and survival differences were analyzed using the log-rank test. The $\chi^{2}$ test or Fisher's exact test was used to compare categorical variables. All reported p values were the results of two-sided tests, and $p<0.05$ was considered statistically significant.

A Cox proportional hazards regression model was employed in univariate and multivariate analyses to identify the significant independent prognostic factors of various clinical parameters for survival. Significant prognostic variables in univariate analysis for OS were included in the multivariate analysis. $\mathrm{p}<0.05$ was considered statistically significant.

\section{Results}

\section{Patients' Characteristics}

Between May 2002 and May 2010, 63 metastatic or recurrent GC patients received platinum-based combination chemotherapy as a first-line therapy. Simultaneously, all patients received medications for hypertension at the diagnosis of metastatic or recurrent GC (table 1). Of these, 30 patients took an ACEI $(n=10)$ or ARB $(n=$ 20). Other antihypertensive drugs included calcium 
channel blockers $(n=33), \beta$-blockers $(n=10)$, and diuretics $(n=13)$. Combination antihypertensive regimens including more than two drugs were administered to 22 patients. The kinds and doses of antihypertensive agents were decided by cardiology specialists at our institution. All patients continued to receive their antihypertensive drugs at least during their chemotherapy. Table 2 shows the characteristics of the ACEI/ARB group $(n=30)$ and the non-ACEI/ARB group $(n=33)$. Baseline characteristics were generally the same between the ACEI/ARB and non-ACEI/ARB groups. Disease status (metastatic vs. recurrent) $(\mathrm{p}=0.09)$ showed a slight difference (not significant) between the ACEI/ARB and non-ACEI/ARB groups. Among 59 patients who experienced disease progression after starting first-line chemotherapy, secondline chemotherapy was administered in $60 \%$ of the ACEI/ $\mathrm{ARB}$ group and $39.4 \%$ of the non-ACEI/ARB group $(\mathrm{p}=$ 0.102 ). Four patients were lost to follow-up without disease progression after first-line chemotherapy, i.e. 3 patients in the ACEI/ARB group and 1 patient in the nonACEI/ARB group.

\section{Outcomes for First-Line Chemotherapy}

The RR for all patients was $25.4 \%$ and the disease control rate was $77.8 \%$ (table 3). The median PFS for first-line chemotherapy was 4.6 (95\% CI 2.86-6.34). There was no significant difference in PFS between the ACEI/ARB group and the non-ACEI/ARB group [5.5 months (95\% CI 3.71-7.29) vs. 4.3 months (95\% CI 2.39-6.21), $\mathrm{p}=$ 0.506] (fig. 1). Via univariate analysis for PFS to first-line chemotherapy, the response to treatment was only associated with a prolonged of PFS $(p=0.034$, table 4$)$. The use of ACEI/ARB did not have significance as a prognostic factor for PFS.

\section{Influence of ACEL/ARB on OS}

During a follow-up of a median of 12.6 months, the median OS for all patients was 9.4 months (95\% CI 6.4812.32). There was a significant difference in OS in the $\mathrm{ACEI} / \mathrm{ARB}$ group compared to the non-ACEI/ARB group (8.2 vs. $13.9, p=0.0095$, fig. 2). In univariate analysis for OS, the response to first-line therapy (responders, patients with CR or PR vs. nonresponders, patients with SD or $\mathrm{PD}$ ), use of $\mathrm{ACEI} / \mathrm{ARB}$, and receiving post-first-line chemotherapy were associated with increased OS. Multivariate analysis revealed that increased OS was significantly associated with use of ACEI/ARB (HR 0.547; 95\% CI $0.308-0.971 \%, \mathrm{p}=0.039$ ) and receiving post-first-line chemotherapy (HR 0.442; 95\% CI $0.249-0.787 \%$, p = 0.005).
Table 1. Number of patients receiving antihypertensive drugs

\begin{tabular}{ll}
\hline Antihypertensive drugs & Patients, $\mathrm{n}$ \\
\hline ACEIs & 10 \\
ARBs & 20 \\
Calcium channel blockers & 33 \\
$\beta$-Blockers & 10 \\
Diuretics & 13 \\
Number of antihypertensive drugs & \\
$\quad 1$ & 41 \\
$\quad 22$ & 22 \\
\hline
\end{tabular}

Table 2. Patients' characteristics

\begin{tabular}{|c|c|c|c|}
\hline Characteristics & ACEI/ARB & Non-ACEI/ARB & $\mathrm{p}$ value \\
\hline \multicolumn{4}{|l|}{ Age, years } \\
\hline Median (range) & \multicolumn{2}{|c|}{$67.0(37-85)$} & \\
\hline$\leq 65$ & 12 & 12 & 0.767 \\
\hline$>65$ & 18 & 21 & \\
\hline \multicolumn{4}{|l|}{ Gender } \\
\hline Male & 20 & 21 & 0.801 \\
\hline Female & 10 & 12 & \\
\hline \multicolumn{4}{|l|}{ PS } \\
\hline 0 & 6 & 10 & 0.348 \\
\hline$\geq 1$ & 24 & 23 & \\
\hline \multicolumn{4}{|l|}{ Disease status } \\
\hline Metastatic & 21 & 29 & 0.09 \\
\hline Recurrent & 9 & 4 & \\
\hline \multicolumn{4}{|l|}{ Grade } \\
\hline Good/moderate & 14 & 17 & 0.701 \\
\hline Poor & 16 & 16 & \\
\hline \multicolumn{4}{|l|}{ Chemotherapy } \\
\hline Only first-line & 12 & 20 & 0.102 \\
\hline $\begin{array}{l}\text { Second-line or } \\
\text { more }\end{array}$ & 18 & 13 & \\
\hline
\end{tabular}

PS $=$ Performance status.

Table 3. Outcomes for first line chemotherapy

n (\%)

$\begin{array}{lc}\text { Response } & \\ \text { Complete response } & 1(1.6) \\ \text { Partial response } & 15(23.8) \\ \text { Stable disease } & 33(52.4) \\ \text { Progressive disease } & 14(22.2) \\ \text { Overall RR } & 16(25.4) \\ \text { Disease control rate } & 49(77.8) \\ \text { Median PFS (95\% CI) for first-line CTx, months } & 4.6(2.86-6.34)\end{array}$

CTx $=$ Chemotherapy 
Table 4. Univariate and multivariate analysis for PFS with first-line chemotherapy

\begin{tabular}{|c|c|c|c|c|c|}
\hline \multirow[t]{2}{*}{ Variable } & & \multicolumn{2}{|l|}{ Univariate } & \multicolumn{2}{|l|}{ Multivariate } \\
\hline & & HR (95\% CI) & $\mathrm{p}$ value & HR (95\% CI) & $\mathrm{p}$ value \\
\hline Age, years & $\begin{array}{l}\leq 65 \\
>65\end{array}$ & $\begin{array}{l}1 \\
1.656(0.949-2.889)\end{array}$ & 0.076 & & \\
\hline Gender & $\begin{array}{l}\text { Male } \\
\text { Female }\end{array}$ & $\begin{array}{l}1.012(0.589-1.738) \\
1\end{array}$ & 0.966 & & \\
\hline PS & $\begin{array}{l}0 \\
\geq 1\end{array}$ & $\begin{array}{l}0.814(0.444-1.492) \\
1\end{array}$ & 0.505 & & \\
\hline Disease status & $\begin{array}{l}\text { Metastatic } \\
\text { Recurrent }\end{array}$ & $\begin{array}{l}0.879(0.460-1.681) \\
1\end{array}$ & 0.696 & & \\
\hline Grade & $\begin{array}{l}\text { Good/Moderate } \\
\text { Poor }\end{array}$ & $\begin{array}{l}0.885(0.527-1.484) \\
1\end{array}$ & 0.643 & & \\
\hline Efficacy of first CTx & $\begin{array}{l}\text { Responder } \\
\text { Nonresponder }\end{array}$ & $\begin{array}{l}0.522(0.286-0.951) \\
1\end{array}$ & 0.034 & $0.522(0.286-0.951)$ & 0.034 \\
\hline Use of ACEI/ARB & $\begin{array}{l}\text { Yes } \\
\text { No }\end{array}$ & $\begin{array}{l}0.839(0.498-1.414) \\
1\end{array}$ & 0.510 & & \\
\hline
\end{tabular}

PS $=$ Performance status

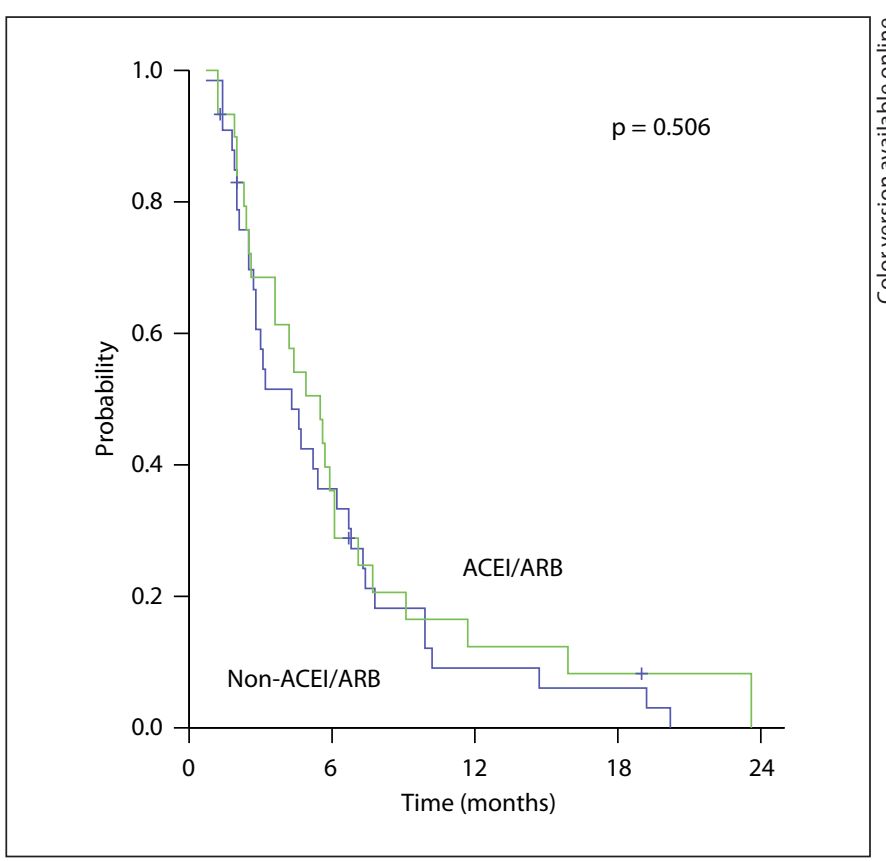

Fig. 1. Kaplan-Meier curves for PFS with first-line chemotherapy by treatment group.

\section{Discussion}

This retrospective study is the first analysis to identify the role of RAS inhibition in the outcomes of patients with AGC and hypertension. The use of ACEI or ARB

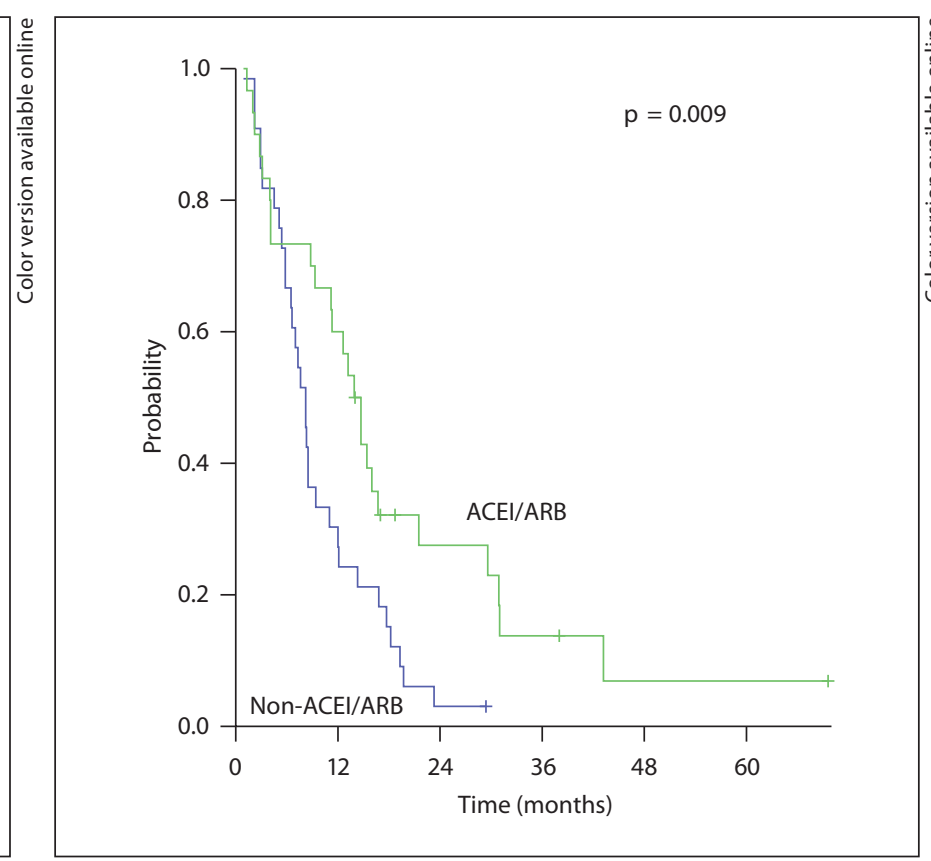

Fig. 2. Kaplan-Meier curves for OS by treatment group.

was associated with longer OS in patients with AGC and hypertension receiving combination chemotherapy as first-line treatment, although it did not affect the RR and PFS for first-line chemotherapy. There was no significant difference in G3/4 toxicities between the ACEI/ARB and 
Table 5. Univariate and multivariate analysis for OS

\begin{tabular}{|c|c|c|c|c|c|}
\hline \multirow[t]{2}{*}{ Variable } & & \multicolumn{2}{|l|}{ Univariate } & \multicolumn{2}{|l|}{ Multivariate } \\
\hline & & HR (95\% CI) & $\mathrm{p}$ value & HR (95\% CI) & $\mathrm{p}$ value \\
\hline Age, years & $\begin{array}{l}\leq 65 \\
>65\end{array}$ & $\begin{array}{l}1 \\
1.282(0.751-2.186)\end{array}$ & 0.363 & & \\
\hline Gender & $\begin{array}{l}\text { Male } \\
\text { Female }\end{array}$ & $\begin{array}{l}1.397(0.797-2.449) \\
1\end{array}$ & 0.244 & & \\
\hline PS & $\begin{array}{l}0 \\
1\end{array}$ & $\begin{array}{l}1 \\
1.007(0.556-1.826)\end{array}$ & 0.981 & & \\
\hline Disease status & $\begin{array}{l}\text { Metastatic } \\
\text { Recurrent }\end{array}$ & $\begin{array}{l}0.696(0.358-1.354) \\
1\end{array}$ & 0.286 & & \\
\hline Grade & $\begin{array}{l}\text { Good/moderate } \\
\text { Poor }\end{array}$ & $\begin{array}{l}0.718(0.425-1.213) \\
1\end{array}$ & 0.215 & & \\
\hline Efficacy of first CTx & $\begin{array}{l}\text { Responder } \\
\text { Nonresponder }\end{array}$ & $\begin{array}{l}0.356(0.182-0.695) \\
1\end{array}$ & 0.002 & $\begin{array}{l}0.659(0.320-1.360) \\
1\end{array}$ & 0.259 \\
\hline Use of ACEI/ARB & $\begin{array}{l}\text { Yes } \\
\text { No }\end{array}$ & $\begin{array}{l}1 \\
2.061(1.178-3.607)\end{array}$ & 0.011 & $\begin{array}{l}1 \\
0.547(0.308-0.971)\end{array}$ & 0.039 \\
\hline Post-first-line CTx & $\begin{array}{l}\text { Yes } \\
\text { No }\end{array}$ & $\begin{array}{l}0.517(0.303-0.883) \\
1\end{array}$ & 0.016 & $\begin{array}{l}0.442(0.249-0.787) \\
1\end{array}$ & 0.005 \\
\hline
\end{tabular}

PS = Performance status; CTx $=$ chemotherapy.

non ACEI/ARB groups (online suppl. table; see www. karger.com/doi/10.1159/000337979 for all online suppl. material). Our finding revealed that inhibition of the RAS in human GC may improve survival, in accordance with a previous report on a human gastric xenograft [21]. Moreover, recently, a favorable impact of RAS inhibition on clinical outcomes was reported in advanced pancreatic cancer [20].

ACEI and ARB are a representative modality for RAS inhibition. ACEIs and ARBs are used as common antihypertensive agents and the reports of organ-protective effects [22] of ACEIs, including inhibition of cardiac hypertrophy, diabetic nephropathy, and diabetic retinopathy, are increasing. With respect to anticancer effects, large epidemiological studies suggest potential protective effects against cancer risk [10] although the results remain controversial. ACEI and ARB could act on tumor progression via two different mechanisms: inhibition of cancer proliferation and/or inhibition of neovascularization. In previous studies on various cancer types, ACEI or ARB showed antiproliferative effects in breast cancer cells $[14,23]$ in a human melanoma xenograft model [24], in murine hepatocellular carcinoma [25], in colorectal cancer liver metastasis [26], and on pancreatic cells [27]. Inhibition of tumor growth involves a decreased expression of VEGF. It has been shown for pancreatic cancer [19, 27] and murine melanoma [28]. In addition, in animal models, ACEI or ARB enhances the effect of the usual chemotherapies as follows: in murine hepatocellular carcinoma in association with interferon [25], in mouse bladder cancer combined with cisplatin by further suppressing angiogenesis [29], by enhancing effects of radiation [30], or in addition to $K_{2}$ vitamin in hepatocellular carcinoma in rats [31]. Recently, in retrospective cohort studies on pancreatic cancer and advanced non-small cell lung cancer, ACEI and ARB were statistically associated with longer patient survival when used with standard first-line chemotherapy [20,32]. Furthermore, ACEI containing thiol groups can directly inhibit the activity of matrix metalloproteinases 2 (MMP-2) and 9 (MMP-9) $[33,34]$. Williams et al. [21] reported that ACEI demonstrated inhibition of a human gastric xenograft, both alone and in combination with cisplatin.

ACEIs block both angiotensin II type- 1 and type- 2 receptors, whereas ARBs block only the type-1 receptor. The role of the angiotensin II type-2 receptor is less studied than that of the angiotensin II type-1 receptor, which is known to induce angiogenesis, proliferation, and inflammation. This distinction between ACEI and ARB may have a different effect on cancer. In our study, although the sample size was not large enough, there was no significant difference in survival between patients taking ACEIs and those taking ARBs $(p=0.69)$. This finding is consistent with that of previous studies. 
Although in our study there was a significant difference in OS in the ACEI/ARB group compared to the nonACEI/ARB group (median OS 8.2 vs. 13.9, $\mathrm{p}=0.0095$ ), a significant difference was not observed in RR and PFS between patients with and without ACEI/ARB. Between the two groups, the baseline characteristics and the rate of administration of second-line chemotherapy did not differ significantly. These findings may be due to the antitumor effect of ACEI or ARB, which is diluted by that of chemotherapeutic agents. Although ACEI, but not $A R B$, showed inhibition of a human gastric xenograft both alone and in combination with cisplatin, all patients in this study received doublet or triplet chemotherapy. In current clinical practice, cisplatin alone is not recommended as first-line chemotherapy in AGC, owing to its low efficacy.

These results should be interpreted with caution. This study has the following limitations: the analysis was con- ducted at a single institution, and there was a small number of patients and a highly selected patient group. Moreover, the review is retrospective and not randomized, and therefore there may be imbalances between treatments in other unmeasured clinical factors. Finally, this study did not consider other important issues such as toxicity profiles, treatment compliance, or quality of life.

In conclusion, our retrospective analysis suggests that ACEL or ARB in combination with standard systemic chemotherapy may improve OS in patients with AGC. A prospective study with a larger population is warranted to confirm our hypothesis.

\section{Disclosure Statement}

The authors have nothing to disclose.

\section{References}

1 Kelley JR, Duggan JM: Gastric cancer epidemiology and risk factors. J Clin Epidemiol 2003;56:1-9.

$\checkmark 2$ Van Cutsem E, Haller D, Ohtsu A: The role of chemotherapy in the current treatment of gastric cancer. Gastric Cancer 2002;5(suppl 1):17-22.

-3 Murad AM, Santiago FF, Petroianu A, Rocha PR, Rodrigues MA, Rausch M: Modified therapy with 5-fluorouracil, doxorubicin, and methotrexate in advanced gastric cancer. Cancer 1993;72:37-41.

-4 Pyrhonen S, Kuitunen T, Nyandoto P, Kouri M: Randomised comparison of fluorouracil, epidoxorubicin and methotrexate (FEMTX) plus supportive care with supportive care alone in patients with non-resectable gastric cancer. Br J Cancer 1995;71:587-591.

5 Schipper DL, Wagener DJ: Chemotherapy of gastric cancer. Anticancer Drugs 1996;7: 137-149.

-6 Glimelius B, Ekstrom K, Hoffman K, Graf W, Sjoden PO, Haglund U, Svensson C, Enander LK, Linne T, Sellstrom H, Heuman R: Randomized comparison between chemotherapy plus best supportive care with best supportive care in advanced gastric cancer. Ann Oncol 1997;8:163-168.

7 Vanhoefer U, Rougier P, Wilke H, Ducreux MP, Lacave AJ, Van Cutsem E, Planker M, Santos JG, Piedbois P, Paillot B, Bodenstein $\mathrm{H}$, Schmoll HJ, Bleiberg H, Nordlinger B, Couvreur ML, Baron B, Wils JA: Final results of a randomized phase III trial of sequential high-dose methotrexate, fluorouracil, and doxorubicin versus etoposide, leucovorin, and fluorouracil versus infusional fluorouracil and cisplatin in ad- vanced gastric cancer: a trial of the European Organization for Research and Treatment of Cancer Gastrointestinal Tract Cancer Cooperative Group. J Clin Oncol 2000;18:2648-2657.

8 Ohtsu A, Shimada Y, Shirao K, Boku N, Hyodo I, Saito H, Yamamichi N, Miyata Y, Ikeda N, Yamamoto S, Fukuda H, Yoshida S: Randomized phase III trial of fluorouracil alone versus fluorouracil plus cisplatin versus uracil and tegafur plus mitomycin in patients with unresectable, advanced gastric cancer: the Japan Clinical Oncology Group Study (JCOG9205). J Clin Oncol 2003;21:5459.

9 Kim NK, Park YS, Heo DS, Suh C, Kim SY, Park KC, Kang YK, Shin DB, Kim HT, Kim HJ, et al: A phase III randomized study of 5 -fluorouracil and cisplatin versus 5 -fluorouracil, doxorubicin, and mitomycin $\mathrm{C}$ versus 5-fluorouracil alone in the treatment of advanced gastric cancer. Cancer 1993;71:38133818.

10 Lever AF, Hole DJ, Gillis CR, McCallum IR, McInnes GT, MacKinnon PL, Meredith PA, Murray LS, Reid JL, Robertson JW: Do inhibitors of angiotensin-I-converting enzyme protect against risk of cancer? Lancet 1998; 352:179-184

11 Friis S, Sorensen HT, Mellemkjaer L, McLaughlin JK, Nielsen GL, Blot WJ, Olsen $\mathrm{JH}$ : Angiotensin-converting enzyme inhibitors and the risk of cancer: a populationbased cohort study in Denmark. Cancer 2001;92:2462-2470.

12 Ager EI, Neo J, Christophi C: The renin-angiotensin system and malignancy. Carcinogenesis 2008;29:1675-1684.
13 Khakoo AY, Sidman RL, Pasqualini R, Arap W: Does the renin-angiotensin system participate in regulation of human vasculogenesis and angiogenesis? Cancer Res 2008;68: 9112-9115.

14 Rhodes DR, Ateeq B, Cao Q, Tomlins SA, Mehra R, Laxman B, Kalyana-Sundaram S, Lonigro RJ, Helgeson BE, Bhojani MS, Rehemtulla A, Kleer CG, Hayes DF, Lucas PC, Varambally S, Chinnaiyan AM: AGTR1 overexpression defines a subset of breast cancer and confers sensitivity to losartan, an AGTR1 antagonist. Proc Natl Acad Sci USA 2009; 106:10284-10289.

15 Juillerat-Jeanneret L, Celerier J, Chapuis Bernasconi C, Nguyen G, Wostl W, Maerki HP, Janzer RC, Corvol P, Gasc JM: Renin and angiotensinogen expression and functions in growth and apoptosis of human glioblastoma. Br J Cancer 2004;90:1059-1068.

-16 Suganuma T, Ino K, Shibata K, Kajiyama H, Nagasaka T, Mizutani S, Kikkawa F: Functional expression of the angiotensin II type 1 receptor in human ovarian carcinoma cells and its blockade therapy resulting in suppression of tumor invasion, angiogenesis, and peritoneal dissemination. Clin Cancer Res 2005;11:2686-2694.

17 Takeda H, Kondo S: Differences between squamous cell carcinoma and keratoacanthoma in angiotensin type-1 receptor expression. Am J Pathol 2001;158:1633-1637.

18 Rocken C, Rohl FW, Diebler E, Lendeckel U, Pross M, Carl-McGrath S, Ebert MP: The angiotensin II/angiotensin II receptor system correlates with nodal spread in intestinal type gastric cancer. Cancer Epidemiol Biomarkers Prev 2007;16:1206-1212. 
19 Noguchi R, Yoshiji H, Ikenaka Y, Namisaki T, Kitade M, Kaji K, Yoshii J, Yanase K, Yamazaki M, Tsujimoto T, Kawaratani $\mathrm{H}$, Fukui H: Synergistic inhibitory effect of gemcitabine and angiotensin type-1 receptor blocker, losartan, on murine pancreatic tumor growth via anti-angiogenic activities. Oncol Rep 2009;22:355-360.

-20 Nakai Y, Isayama H, Ijichi H, Sasaki T, Sasahira N, Hirano K, Kogure H, Kawakubo K, Yagioka H, Yashima Y, Mizuno S, Yamamoto $\mathrm{K}$, Arizumi T, Togawa O, Matsubara S, Tsujino T, Tateishi K, Tada M, Omata M, Koike $\mathrm{K}$ : Inhibition of renin-angiotensin system affects prognosis of advanced pancreatic cancer receiving gemcitabine. $\mathrm{Br} \mathrm{J}$ Cancer 2010;103:1644-1648.

21 Williams RN, Parsons SL, Morris TM, Rowlands BJ, Watson SA: Inhibition of matrix metalloproteinase activity and growth of gastric adenocarcinoma cells by an angiotensin converting enzyme inhibitor in in vitro and murine models. Eur J Surg Oncol 2005;31:1042-1050.

22 Grandi AM, Maresca AM: Blockade of the renin-angiotensin-aldosterone system: effects on hypertensive target organ damage. Cardiovasc Hematol Agents Med Chem 2006;4:219-228.

23 Puddefoot JR, Udeozo UK, Barker S, Vinson GP: The role of angiotensin II in the regulation of breast cancer cell adhesion and invasion. Endocr Relat Cancer 2006;13:895-903.
24 de Groot-Besseling RR, Ruers TJ, van Kraats AA, Poelen GJ, Ruiter DJ, de Waal RM, Westphal JR: Anti-tumor activity of a combination of plasminogen activator and captopril in a human melanoma xenograft model. Int J Cancer 2004;112:329-334.

25 Noguchi R, Yoshiji H, Kuriyama S, Yoshii J, Ikenaka Y, Yanase K, Namisaki T, Kitade M, Yamazaki M, Mitoro A, Tsujinoue H, Imazu H, Masaki T, Fukui H: Combination of interferon-beta and the angiotensin-converting enzyme inhibitor, perindopril, attenuates murine hepatocellular carcinoma development and angiogenesis. Clin Cancer Res 2003;9:6038-6045.

26 Neo JH, Malcontenti-Wilson C, Muralidharan V, Christophi C: Effect of ACE inhibitors and angiotensin II receptor antagonists in a mouse model of colorectal cancer liver metastases. J Gastroenterol Hepatol 2007;22: 577-584.

27 Arafat HA, Gong Q, Chipitsyna G, Rizvi A, Saa CT, Yeo CJ: Antihypertensives as novel antineoplastics: angiotensin-I-converting enzyme inhibitors and angiotensin II type 1 receptor blockers in pancreatic ductal adenocarcinoma. J Am Coll Surg 2007;204:9961005, discussion 1005-1006.

28 Otake AH, Mattar AL, Freitas HC, Machado CM, Nonogaki S, Fujihara CK, Zatz R, Chammas R: Inhibition of angiotensin II receptor 1 limits tumor-associated angiogenesis and attenuates growth of murine melanoma. Cancer Chemother Pharmacol 2010; 66:79-87.

-29 Kosugi M, Miyajima A, Kikuchi E, Kosaka T, Horiguchi Y, Murai M, Oya M: Angiotensin ii type 1 receptor antagonist enhances cisdichlorodiammineplatinum-induced cytotoxicity in mouse xenograft model of bladder cancer. Urology 2009;73:655-660.
30 Ohnuma Y, Toda M, Fujita M, Hosono K, Suzuki T, Ogawa Y, Amano H, Kitasato H, Hayakawa K, Majima M: Blockade of an angiotensin type I receptor enhances effects of radiation on tumor growth and tumor-associated angiogenesis by reducing vascular endothelial growth factor expression. Biomed Pharmacother 2009;63:136-145.

>31 Yoshiji H, Kuriyama S, Noguchi R, Yoshii J, Ikenaka Y, Yanase K, Namisaki T, Kitade M, Yamazaki M, Masaki T, Fukui H: Combination of vitamin $\mathrm{K}_{2}$ and the angiotensin-converting enzyme inhibitor, perindopril, attenuates the liver enzyme-altered preneoplastic lesions in rats via angiogenesis suppression. J Hepatol 2005;42:687-693.

$\checkmark 32$ Wilop S, von Hobe S, Crysandt M, Esser A, Osieka R, Jost E: Impact of angiotensin I converting enzyme inhibitors and angiotensin II type 1 receptor blockers on survival in patients with advanced non-small-cell lung cancer undergoing first-line platinum-based chemotherapy. J Cancer Res Clin Oncol 2009;135:1429-1435.

33 Deshayes F, Nahmias C: Angiotensin receptors: a new role in cancer? Trends Endocrinol Metab 2005;16:293-299.

>34 Volpert OV, Ward WF, Lingen MW, Chesler L, Solt DB, Johnson MD, Molteni A, Polverini PJ, Bouck NP: Captopril inhibits angiogenesis and slows the growth of experimental tumors in rats. J Clin Invest 1996;98:671679. 